\title{
Zeamatin, an antifungal protein from maize with membrane-permeabilizing activity
}

\author{
WaLden K. Roberts ${ }^{1 *}$ and Claude P. SelitrennikofF ${ }^{2}$ \\ ${ }^{1}$ Department of Microbiology and Immunology and ${ }^{2}$ Department of Cellular and Structural Biology, University of \\ Colorado Health Sciences Center, Denver, CO 80262, USA
}

(Received 16 February 1990; revised 1 May 1990; accepted 22 May 1990)

\begin{abstract}
A $22 \mathrm{kDa}$ antifungal protein (zeamatin) was purified from Zea mays seeds. It was identified and assayed by its unusual property of acting synergistically with nikkomycin to inhibit growth of Candida albicans. Alone, it inhibited growth in suspension culture of $C$. albicans, Neurospora crassa and Trichoderma reesei. Zeamatin contained no detectable chitinase, 1,3- $\beta$-glucanase or ribosome-inactivating protein activity, enzymes present in a variety of plants that have been shown to have antifungal properties. At low concentrations zeamatin caused the rapid release of cytoplasmic material from $C$. albicans and $N$. crassa. This was confirmed microscopically by observing zeamatin-induced hyphal rupture of these fungi. These results suggest that zeamatin permeabilizes the fungal plasma membrane. We believe zeamatin to be a representative of a previously unrecognized class of plant antifungal proteins.
\end{abstract}

\section{Introduction}

Plants lack an immune system and must depend on other mechanisms to defend themselves against microbial invaders. One such mechanism is the synthesis of proteins that act specifically to inhibit microbial growth. For example, seeds of many such plants contain high concentrations of chitinases, glucanases and ribosomeinactivating proteins that may help protect seeds and seedlings from fungal infection (Schlumbaum et al., 1986; Roberts \& Selitrennikoff, 1986a, 1988; Mauch et al., 1988).

We have previously described the antifungal activity of chitinases isolated from the seeds of wheat, barley and maize (Roberts \& Selitrennikoff, 1988). The maize chitinase preparation was found to have the unusual property of causing a 100 -fold reduction in the minimum dose of nikkomycin required to inhibit growth of Candida albicans (Roberts et al., 1988). Careful analysis of the maize preparation revealed several proteins and several enzyme activities, and it was not clear which protein was responsible for the synergistic activity (Roberts et al., 1988). We report here purification of this synergistic protein (zeamatin) to apparent homogeneity. Also, evidence is provided that zeamatin is not an enzyme at all, but a protein that exerts its antifungal effects by damaging fungal membranes.

\section{Methods}

Antifungal assays. The assays for inhibition of hyphal extension of Trichoderma reesei and Neurospora crassa were carried out on agar plates as described previously (Roberts \& Selitrennikoff, 1986b). In these assays, dilutions of chitinase or zeamatin samples were added to sterile paper discs surrounding a central fungal inoculum, the agar plates were incubated to permit outward growth of the fungi, and antifungal protein was detected by the appearance of crescents of retarded growth around the discs. The standard assay for zeamatin activity was growth inhibition of $C$. albicans suspended in agar and was done in the presence of nikkomycin $\mathrm{Z}$ (Calbiochem) at sub-inhibitory concentrations. This was done as described previously (Roberts et al., 1988), but with several modifications. Agar $(2 \%, w / v)$ in $4 \%(w / v)$ carrot juice was autoclaved and cooled to $45^{\circ} \mathrm{C}$. A suspension of $C$. albicans was added to a concentration of $1 \times 10^{4}$ organisms ml-1, nikkomycin $\mathrm{Z}$ was added to a concentration of $0.2 \mu \mathrm{g} \mathrm{ml}^{-1}$ and $10 \mathrm{ml}$ portions of the liquid agar suspension were added to Petri plates. The concentration of nikkomycin used was approximately 20 -fold lower than the concentration of nikkomycin that alone inhibited growth of $C$. albicans. Sterile paper discs were placed on the solidified agar, $30 \mu \mathrm{l}$ samples of diluted zeamatin preparations were added to each disc, and the plates were incubated overnight at $37^{\circ} \mathrm{C}$. Clear zones of no fungal growth were seen around discs containing inhibitory concentrations of zeamatin, and units of zeamatin activity were defined as the reciprocal of the highest sample dilution that produced a detectable zone of growth inhibition.

To determine zeamatin-induced inhibition of fungal growth in suspension culture, we devised empirically a medium that was low in salts, to promote zeamatin activity, yet adequate in nutrients to permit good fungal growth. This medium contained $0.05 \%$ glucose, $10 \%$ of the recommended concentration of Minimum Essential Medium amino 
acids (Flow Laboratories) used to prepare tissue culture medium and $10 \%$ of the final concentration of salts used by Vogel (1964) to prepare fungal test medium N. $T$. reese $i$ and $N$. crassa spores and $C$. albicans yeast cells were suspended in this medium at a concentration of approximately $1 \times 10^{3}$ organisms $\mathrm{ml}^{-1}$. Portions $(0.5 \mathrm{ml})$ of the fungal suspensions were added to wells of a Costar 24-well tissue culture plate, zeamatin was added at varying concentrations, and the plate incubated at $37{ }^{\circ} \mathrm{C}$ for $24 \mathrm{~h}$. Inhibition was defined as no visible growth at the end of this time period.

Enzyme assays. Carbohydrase assays were done by suspending or dissolving chitin, mannan, laminarin (a $\beta$-1,3-linked glucan) or pustulan (a $\beta$-1,6-linked glucan) each at $2 \mathrm{mg} \mathrm{ml}^{-1}$ in 0.05 M-potassium phosphate buffer ( $\mathrm{pH} 6.0)$, and incubating substrate with zeamatin at $37^{\circ} \mathrm{C}$ for $20 \mathrm{~min}$, except for chitin suspensions which were incubated in shaking tubes at $37^{\circ} \mathrm{C}$ for $4 \mathrm{~h}$. Carbohydrase activity was detected as an increase in reducing sugar (Somogyi, 1952), and activities calculated as $\mu \mathrm{mol}$ glucose released. The $\beta$ - $N$-acetylhexosaminidase and phospholipase $C$ activities were assayed using the chromogenic substrates $p$ nitrophenyl- $N$-acetyl- $\beta$-D-glucosaminide and $p$-nitrophenylphosphorylcholine (Sigma), respectively, following the manufacturer's instructions. Ribosome-inactivating protein activity was measured as described previously (Roberts \& Selitrennikoff, $1986 b$ ). Ribonuclease activity was determined by incubating enzyme or zeamatin at $37^{\circ} \mathrm{C}$ for 30 min with $100 \mu \mathrm{g}$ mammalian cytoplasmic $\mathrm{RNA} \mathrm{ml}^{-1}$ and measuring the increase in $A_{260}$ following precipitation with $10 \%(w / v)$ trichloroacetic acid. Protease activity was assayed by adding enzyme or zeamatin to chicken ovalbumin, BSA and pancreatic ribonuclease (each at $1 \mathrm{mg} \mathrm{ml}^{-1}$ ), incubating the samples at $37^{\circ} \mathrm{C}$ for $1 \mathrm{~h}$, and examining the incubation mixtures for cleavage products by SDSPAGE. Purified zeamatin did not show detectable activity in any of the enzyme assays tested, even at concentrations as high as $10-100 \mu \mathrm{g}$ zeamatin $\mathrm{ml}^{-1}$. In contrast, as positive controls the corresponding commercial enzymes showed high activity at $1 \mu \mathrm{g}$ protein $\mathrm{ml}^{-1}$ in all the above assays.

Purification of zeamatin. A variety of commercial sources of maize seeds and ground seeds (corn meal) were used in purification; all yielded similar quantities of zeamatin, except for popcorn, where no zeamatin activity was detected. The extraction of ground maize seeds and the purification of zeamatin using CM-Sephadex column chromatography was described previously (Roberts et al., 1988). Briefly, the protein that was precipitated by ammonium sulphate between 30 and $55 \%$ saturation was added to a CM-Sephadex column and the column was washed with buffered $0.01 \mathrm{M}-\mathrm{NaCl}$ until the $A_{280}$ of the effluent was below $0 \cdot 2$. The bound proteins were eluted with a linear gradient of $220 \mathrm{ml}$ buffered $0.2 \mathrm{M}-\mathrm{NaCl}$ passing into $220 \mathrm{ml}$ buffered $0.01 \mathrm{M}-\mathrm{NaCl}$. In the present study, gradient elution on a $2.4 \times 21 \mathrm{~cm}$ column was done at a slower elution rate, with $6 \mathrm{ml}$ fractions being collected every $7 \mathrm{~min}$, resulting in four protein peaks in the elution profile (see Fig. 2) rather than three peaks as observed previously. Fractions 42 to 48 (peak 3) from CM-Sephadex chromatography were combined and further purified by hydrophobic chromatography on columns of Phenyl-Sepharose CL-4B (Pharmacia). A Phenyl-Sepharose column $(1.2 \times 12 \mathrm{~cm})$ was prepared, washed extensively with $1 \mathrm{M}-\mathrm{NaCl}$, and equilibrated at $23^{\circ} \mathrm{C}$ with a $0.1 \mathrm{M}-\mathrm{NaCl}$ solution containing $5 \mathrm{~mm}$-sodium phosphate $(\mathrm{pH} 7.0)$ and $1 \mathrm{~mm}-$ EDTA. A $3 \mathrm{ml}$ portion of the peak 3 fraction was added directly to the column, washed through and eluted with equilibration buffer, and $3 \mathrm{ml}$ fractions were collected every $6 \mathrm{~min}$. The column was eluted finally with $50 \%(\mathrm{v} / \mathrm{v})$ ethylene glycol in water to give the elution profile shown in Fig. 3 (filled circles). This chromatography cycle was repeated several times and the peak 2 fractions (Fig. 3) were combined and concentrated by ultrafiltration using Diaflo YM 10 membranes (Amicon) to yield the purified zeamatin used in subsequent assays.
Purification was monitored by SDS-PAGE according to the procedure of Laemmli (1970) using $12 \%(\mathrm{w} / \mathrm{v})$ acrylamide and $0.1 \% \mathrm{SDS}$. Prior to electrophoresis, samples were heated at $95^{\circ} \mathrm{C}$ for $5 \mathrm{~min}$ in sample buffer either with (reducing conditions) or without (non-reducing conditions) $5 \%(\mathrm{v} / \mathrm{v}) 2$-mercaptoethanol.

Zeamatin-induced membrane permeabilization. Release of ultravioletabsorbing material from $C$. albicans was done essentially as described by Yphantis et al. (1967), with cells suspended in water $\left(2 \mathrm{mg} \mathrm{ml}^{-1}\right)$ and incubated at $37^{\circ} \mathrm{C}$ for $30 \mathrm{~min}$ with the indicated concentrations of proteins. Cells were removed by centrifugation and the $A_{260}$ of supernatant solutions measured. Release of amino $\left[1{ }^{-14} \mathrm{C}\right]$ isobutyric acid (ICN; $40 \mu \mathrm{Ci} \mathrm{mmol}^{-1}, 1.48 \mathrm{MBq} \mathrm{mmol}^{-1}$ ) from $N$. crassa was determined by a modification of the procedure of Georgopapadakou $e t$ al. (1987). N. crassa macroconidia were grown for $3 \mathrm{~h}$ at $30^{\circ} \mathrm{C}$ (Quigley et al., 1987), amino $\left[1^{-14} \mathrm{C}\right]$ isobutyric acid added to a final concentration of $0.5 \mathrm{~mm}$ and $0.05 \mu \mathrm{Ci} \mathrm{ml}^{-1}$, and incubation continued for $2.5 \mathrm{~h}$. Radioactive germinated macroconidia were harvested by centrifugation, washed twice with cold water, and cell concentrations adjusted with water to $2.5 \times 10^{6}$ cells ml-1. Samples were incubated at $30^{\circ} \mathrm{C}$ or $0{ }^{\circ} \mathrm{C}$ with $12 \mu \mathrm{g} \mathrm{ml}^{-1}$ of the agents indicated, and the amount of cellassociated radioactivity remaining determined by collecting cells on Millipore filters and counting.

Zeamatin-induced hyphal rupture. $N$. crassa macroconidia were germinated by incubation at $37^{\circ} \mathrm{C}$ for $6 \mathrm{~h}$ in $4 \%$ carrot juice (prepared by autoclaving $4 \mathrm{~g}$ sliced carrots in $96 \mathrm{ml}$ water for $20 \mathrm{~min}$ ). Hyphae were concentrated by centrifugation and resuspended in $4 \%(\mathrm{w} / \mathrm{v})$ carrot juice. Portions of the suspension were adjusted to $0.005 \%$ methylene blue and incubated at $23{ }^{\circ} \mathrm{C}$ for $10 \mathrm{~min}$ in the presence of zeamatin or other proteins. Hyphae were photographed using phasecontrast light microscopy at $250 \times$ magnification.

\section{Results}

\section{Antifungal assays}

Previously, we utilized a hyphal extension-inhibition assay on agar to purify antifungal chitinases from several grains (Roberts \& Selitrennikoff, 1988). This assay was of little value for zeamatin purification, since Zea mays contained several chitinases that had similar properties to zeamatin and effectively inhibited hyphal extension. However, the ability to act synergistically with nikkomycin was unique to zeamatin, and this property was the basis of a specific and sensitive zeamatin assay shown in Fig. 1. In agar suspensions, the addition of zeamatin alone to discs at concentrations as high at $100 \mu \mathrm{g}$ protein $\mathrm{ml}^{-1}$ did not inhibit growth of $C$. albicans (Fig. 1a). However, inclusion of nikkomycin $Z$ at a sub-inhibitory concentration in the agar produced detectable growth inhibition with as little as $3 \mu \mathrm{g}$ zeamatin $\mathrm{ml}^{-1}$ (Fig. 1 b). This was the assay used in the zeamatin purification procedures described below.

\section{Zeamatin purification}

The initial steps of zeamatin purification were done as previously described (Roberts et al., 1988). Protein was 

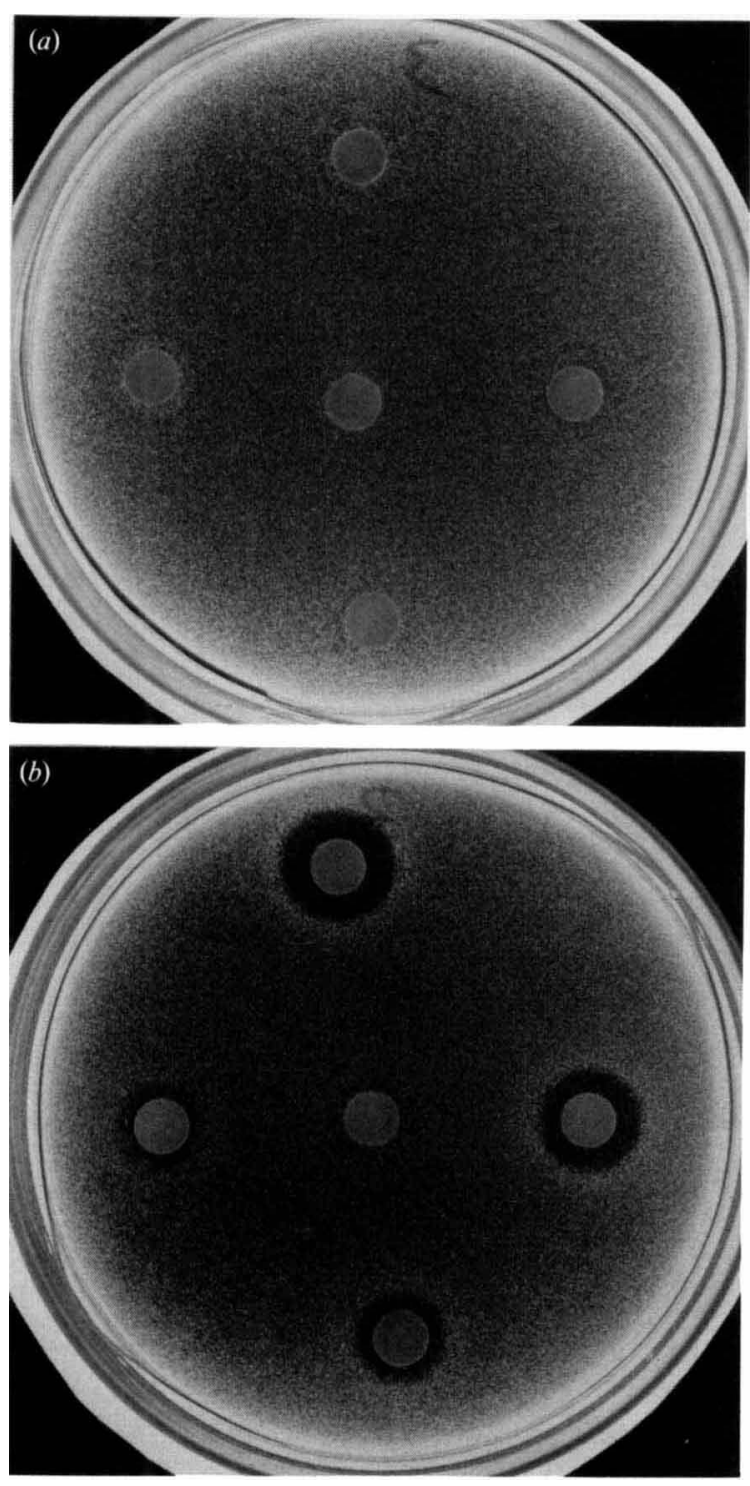

Fig. 1. Synergistic growth inhibition of $C$. albicans by zeamatin and nikkomycin. Agar suspensions of $C$. albicans were grown in the absence (a) or presence (b) of $0 \cdot 2 \mu \mathrm{g}$ nikkomycin $\mathrm{Z} \mathrm{ml}^{-1}$. Starting at the top and proceeding clockwise ending in the centre, discs in both $(a)$ and $(b)$ contained $30 \mu \mathrm{l}$ zeamatin added at concentrations of 100,30,10,3 and $1 \mu \mathrm{g} \mathrm{ml}^{-1}$, respectively.

extracted from ground maize seeds, a 30 to $55 \%(w / v)$ ammonium sulphate fraction obtained, and this fraction partially purified by CM-Sephadex column chromatography. Antifungal activities were assayed in fractions across each of the peaks (Fig. 2a). The assays used were hyphal extension inhibition of $T$. reesei, an activity common to plant chitinases (Roberts \& Selitrennikoff, 1988), hyphal extension inhibition of $N$. crassa, and growth inhibition of $C$. albicans in the presence of sub- inhibitory concentrations of nikkomycin. Anti-Neurospora and anti-Candida activities were found only in the peak 3 protein fractions, whereas anti-Trichoderma activity was observed in all peak fractions.

In an effort to correlate peak 3 antifungal activity with enzyme activity, chitinase, glucanase, and $\beta$ - $N$-acetylhexosaminidase were assayed across all four peak fractions (Fig. 2b). Chitinase activity was found in all four peaks and we assume that this contributed wholly or partially to the observed inhibition of hyphal extension of $T$. reesei. In contrast, a single peak of glucanase activity was observed at fraction 47 and a single peak of $\beta$ - $N$-acetylhexosaminidase was detected at fraction 40 . The peak of anti-Neurospora and anti-Candida activities was located around fraction 44, and did not coincide precisely with peak activity for any of the three enzymes tested.

Fractions 42 to 48 from CM-Sephadex column chromatography were combined and subjected to additional protein purification procedures. One effective procedure was hydrophobic column chromatography using Phenyl-Sepharose CL-4B. When this chromatography was done in the usual manner, approximately $90 \%$ of the protein bound to the column in $1 \mathrm{M}^{-}$ ammonium sulphate and could be eluted with $50 \%(\mathrm{v} / \mathrm{v})$ ethylene glycol, (Fig. 3, open circles). However, a more interesting and useful elution pattern occurred when the sample was loaded into the column at a lower salt concentration $(0 \cdot 1 \mathrm{M}-\mathrm{NaCl})$ to reduce the hydrophobic interaction between proteins and Phenyl-Sepharose (Fig. 3 , filled circles). In this case, a large protein fraction passed directly through the column (peak 1), followed by another large fraction whose passage through the column was retarded (peak 2), and finally a small fraction that bound and was eluted with $50 \%$ ethylene glycol (peak 3 ). This separation based upon retardation was novel and unexpected, since protein fractionation on a hydrophobic matrix normally involves differential protein binding and elution. Analysis of the three peaks revealed all chitinase activity in peak 1 , all zeamatin (antiCandida) activity in peak 2, all glucanase activity in peak 3 , and the $\beta$ - $N$-acetylhexosaminidase activity was not recovered from the column.

Using this procedure, approximately $1 \mathrm{mg}$ zeamatin was isolated per $100 \mathrm{~g}$ of maize seeds, and it showed a specific activity in the anti-Candida assay of 400 units (mg protein $)^{-1}$. This represented a 50 -fold purification relative to the original extract. Although this procedure yielded pure zeamatin as analysed by SDS-PAGE (Fig. 4), Phenyl-Sepharose has a relatively low capacity for this type of retarded flow separation. More recently, reverse-phase HPLC on C-18 columns has been used to prepare pure zeamatin in larger quantities (A. Vigers, unpublished results). 

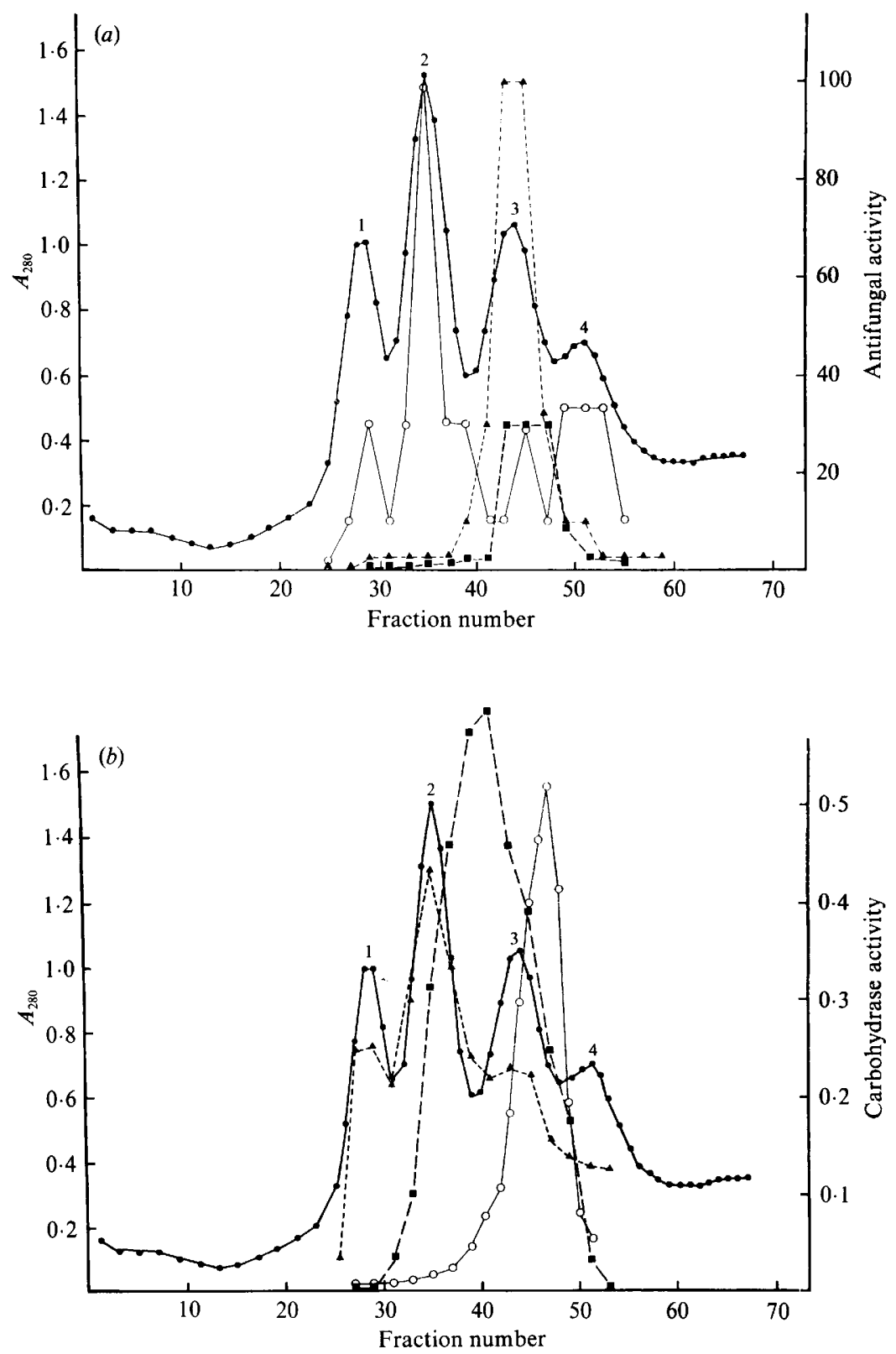

Fig. 2. Partial purification of zeamatin by CM-Sephadex column chromatography. (a) Antifungal activity is expressed as the reciprocal of the highest dilution that produced detectable growth inhibition in the assay. $-A_{280} ; O-O$, hyphal extension-inhibition of $T$. reesei; $-\square$, hyphal extension-inhibition of $N$. crassa; and $\mathbf{\Delta}--\mathbf{\Delta}$, synergy with nikkomycin to inhibit growth of $C$. albicans. (b) Enzyme activity is expressed as $\mu \mathrm{mol}$ glucose (for chitinase and glucanase) or $p$-nitrophenol (for $\beta$ - $N$-acetylhexosaminidase) released under our standard assay conditions (see Methods) using $50 \mu \mathrm{l} \mathrm{from} \mathrm{each} \mathrm{fraction} \mathrm{in} 0.5 \mathrm{ml}$ substrate (chitinase), $5 \mu \mathrm{l}$ in $0.5 \mathrm{ml}$ substrate (glucanase), and $5 \mu \mathrm{l}$ in $0.1 \mathrm{ml}$ substrate $\left(\beta-N\right.$-acetylhexosaminidase). - $-A_{280} ; \boldsymbol{\Delta}---\boldsymbol{\Delta}$, chitinase activity; $\mathrm{O}-\mathrm{O}, 1,3-\beta$-glucanase activity; and $\square--\square, \beta$ - $N$-acetylhexosaminidase activity.

\section{Properties of purified zeamatin}

The purification of zeamatin was monitored by SDSPAGE on non-reducing, $12 \%$ acrylamide gels (Fig. 4). Gels were initially run under non-reducing conditions since zeamatin in these gels could be renatured and a bioautography technique used to demonstrate anti-
Candida activity associated only with a protein band migrating at $19 \mathrm{kDa}$ (A. Vigers and others, unpublished results). Proteins found in single peak fractions from CM-Sephadex column chromatography (Fig. 2) are shown in lanes $1-4$, respectively. Further purification of the peak 3 fraction by Phenyl-Sepharose column chromatography produced three peaks (Fig. 3), that were 


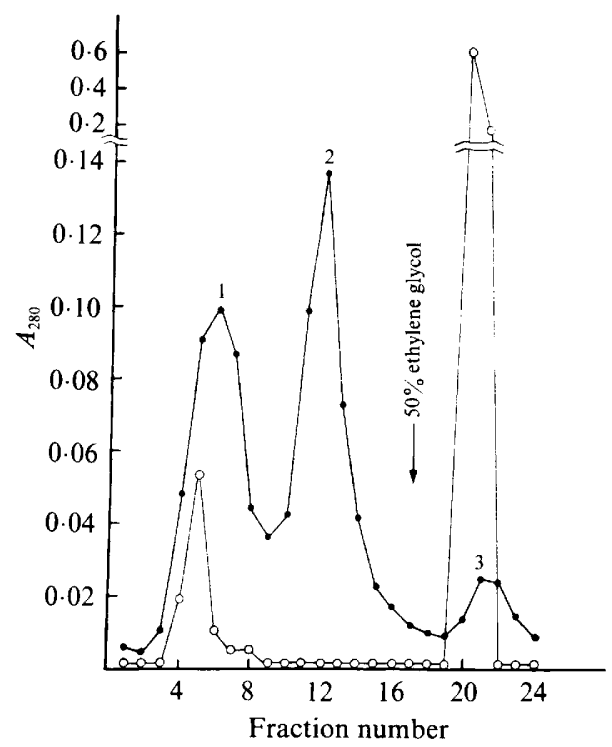

Fig. 3. Purification of zeamatin by Phenyl-Sepharose column chromatography. Equivalent samples of peak 3 protein from CM-Sephadex chromatography (Fig. 2) were washed through the column in either $1 \mathrm{M}$ ammonium sulphate (open circles) or buffered $0.1 \mathrm{M}-\mathrm{NaCl}$ (filled circles). At fraction 17 the elution buffer was changed to $50 \%(\mathrm{v} / \mathrm{v})$ ethylene glycol in water.

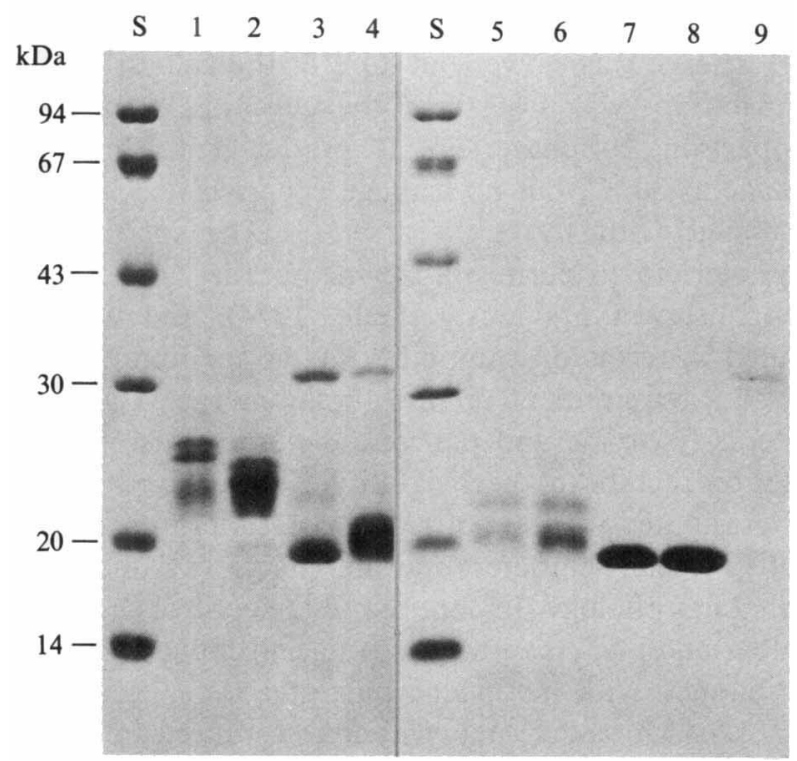

Fig. 4. Analysis of column chromatography samples by SDS-PAGE. Electrophoresis was done in $12 \%$ acrylamide gels under non-reducing conditions, and protein bands were detected by staining with Coomassie Brilliant Blue. Lane S, molecular mass markers; lanes 1-4, peaks 1-4 respectively from CM-Sephadex chromatography (Fig. 2); lanes 5 and 6, peak 1 (Fig. 3, filled circles) from two separate PhenylSepharose chromatography fractionations; lanes 7 and 8, peak 2 (Fig. 3) from two separate fractionations; lane 9, peak 3 (Fig. 3, filled circles). All lanes contained 8-30 $\mu \mathrm{g}$ protein except for lane 9 (2.5 $\mu \mathrm{g}$ protein).

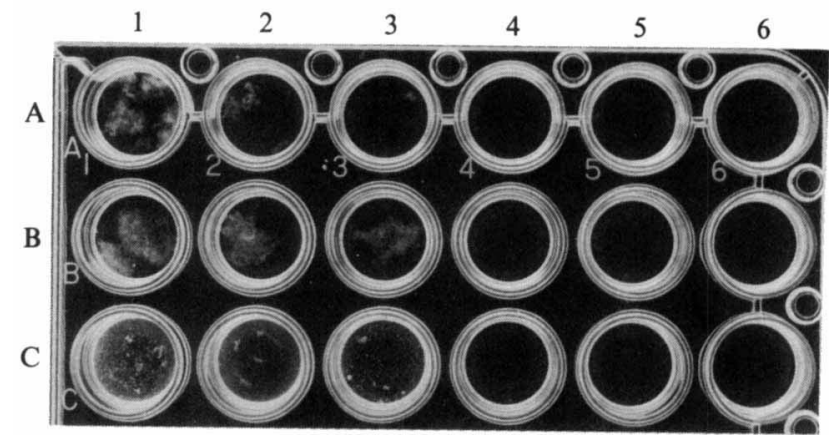

Fig. 5. Antifungal activity of zeamatin in suspension culture in a Costar tissue culture plate. The horizontal rows of wells contained suspensions of $T$. reesei (A), N. crassa (B) and C. albicans (C). Pure zeamatin was added to these suspensions to final concentrations of $(\mu \mathrm{g}$ $\mathrm{ml}^{-1}$ ); 0 (vertical row 1), 1.25 (row 2), 2.5 (row 3), 5.0 (row 4), 10.0 (row 5) and 20.0 (row 6). The plate was incubated at $37^{\circ} \mathrm{C}$ for $24 \mathrm{~h}$ and photographed.

added to lanes 5 and 6 (peak 1), lanes 7 and 8 (peak 2), and lane 9 (peak 3). Purified zeamatin (lanes 7 and 8) migrated under these conditions as a single band with an apparent molecular mass of $19 \mathrm{kDa}$. SDS-PAGE under reducing conditions (not shown) gave a higher value of $22 \mathrm{kDa}$, possibly due to reduction of zeamatin's disulphide bonds to produce a less compact conformation. We consider $22 \mathrm{kDa}$ to be a better estimate of zeamatin's molecular mass.

Of the three carbohydrase activities (chitinase, 1,3- $\beta$ glucanase, $\beta$ - $N$-acetylhexosaminidase) present in the peak $3 \mathrm{CM}$-Sephadex fraction (Fig. $2 b$ ), none could be detected following purification of zeamatin using Phenyl-Sepharose. These enzyme activities were absent at zeamatin concentrations as high as $100 \mu \mathrm{g} \mathrm{m}^{-1}$. In addition, zeamatin was assayed for ribosome-inactivating protein, mannanase, protease, ribonuclease and phospholipase $\mathrm{C}$ activities at concentrations between 10 and $100 \mu \mathrm{g}$ zeamatin $\mathrm{ml}^{-1}$ and all assays proved negative. Zeamatin was stable for over 6 weeks at $4{ }^{\circ} \mathrm{C}$, but lost all antifungal activity upon heating at $70^{\circ} \mathrm{C}$ for $15 \mathrm{~min}$.

Purified zeamatin acted synergistically with nikkomycin to inhibit growth of both C. albicans and N. crassa in suspension cultures containing $4 \%(\mathrm{w} / \mathrm{v})$ carrot juice as the medium. The addition of $2 \mu \mathrm{g}$ zeamatin $\mathrm{ml}^{-1}$ to the culture medium reduced the minimum inhibitory concentration of nikkomycin from $6 \mu \mathrm{g} \mathrm{ml}^{-1}$ to $0.06 \mu \mathrm{g} \mathrm{ml}^{-1}$ for C. albicans and from $6 \mu \mathrm{g} \mathrm{ml}^{-1}$ to $0.2 \mu \mathrm{g} \mathrm{ml}^{-1}$ for $N$. crassa (data not shown). In addition, zeamatin alone was able to inhibit effectively fungal growth in suspension cultures (Fig. 5). As little as $5 \mu \mathrm{g}$ zeamatin $\mathrm{ml}^{-1}$ (vertical row 4) inhibited growth of $T$. reesei (row A), $N$. crassa (row B), and C. albicans (row C). This inhibition was 

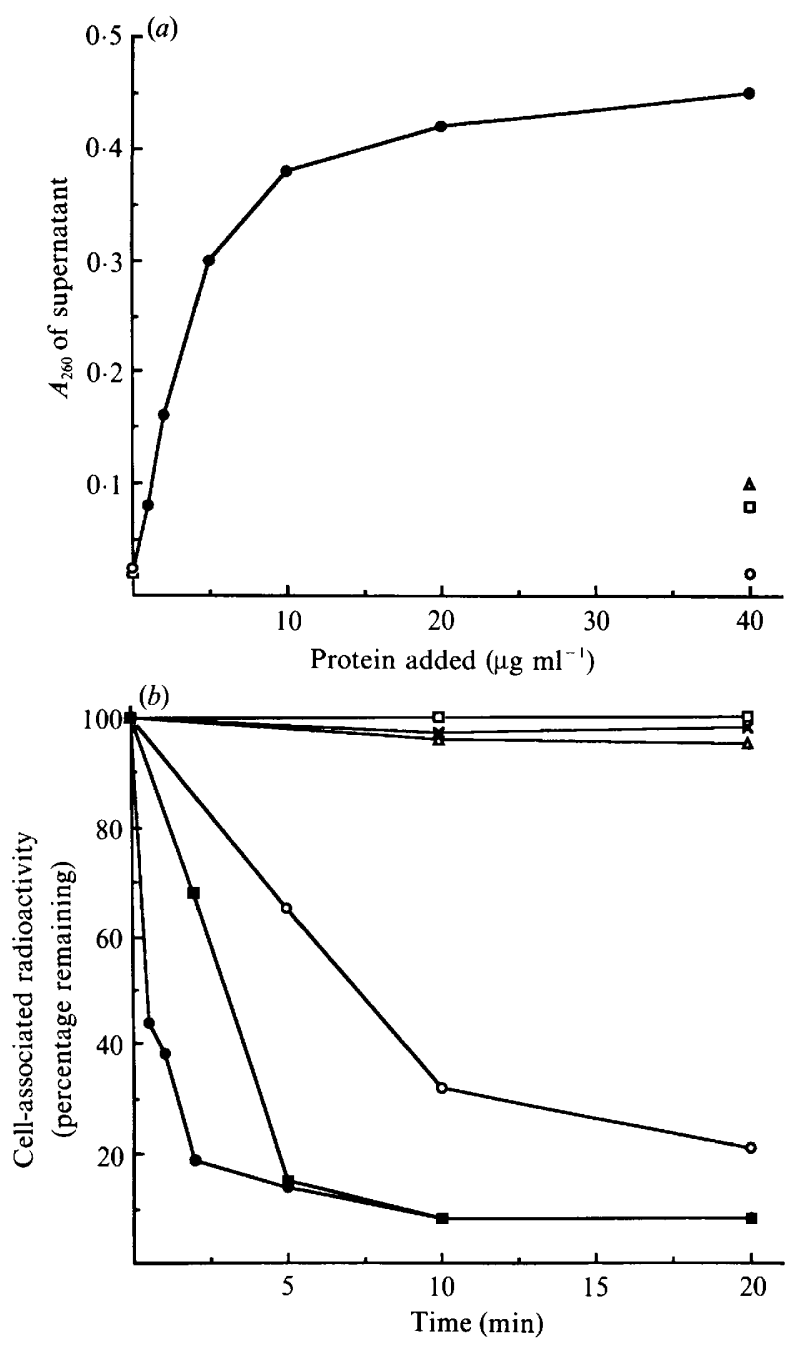

Fig. 6. Zeamatin-induced membrane permeabilization. (a) Release of ultraviolet-absorbing material from C. albicans following incubation at $37^{\circ} \mathrm{C}$ for $30 \mathrm{~min}$ with the indicated concentrations of zeamatin $(\Theta)$, lysozyme $(\triangle)$, cytochrome $c(\square)$ or BSA (O). (b) Release of amino[1${ }^{14} \mathrm{C}$ ]isobutyric acid from $N$. crassa following incubation with $12 \mu \mathrm{g} \mathrm{ml}^{-1}$ zeamatin at $30^{\circ} \mathrm{C}(\mathrm{O})$, zeamatin at $4{ }^{\circ} \mathrm{C}(\mathrm{O})$, amphotericin $\mathrm{B}$ at $30^{\circ} \mathrm{C}(\square)$, amphotericin $\mathrm{B}$ at $4^{\circ} \mathrm{C}(\square)$, pancreatic ribonuclease at $30^{\circ} \mathrm{C}(\triangle)$ and lysozyme at $30^{\circ} \mathrm{C}(\mathrm{X})$.

found to be quite sensitive to the medium used for fungal growth; higher concentrations of zeamatin were required for growth inhibition in rich media or any medium containing moderate salt concentrations. The assays shown in Fig. 5 used a dilute, defined medium that was able to support fungal growth while permitting good zeamatin-induced growth inhibition. Adjusting this medium to $0.03 \mathrm{M}-\mathrm{NaCl}$ raised the minimum inhibitory concentration of zeamatin from 5 to $20 \mu \mathrm{g} \mathrm{ml}^{-1}$, whereas $80 \mu \mathrm{g}$ zeamatin $\mathrm{ml}^{-1}$ was required to inhibit growth in $0 \cdot 1 \mathrm{M}-\mathrm{NaCl}$ (results not shown).

\section{Zeamatin-induced membrane lysis}

The enzyme assays summarized above were not helpful in identifying the antifungal mechanism of action of zeamatin. The fungal cell wall seemed an unlikely target site since purified zeamatin contained no detectable chitinase, glucanase, mannanase or proteinase activity. However, the fungal cell membrane remained a possible site of action. Several experimental approaches were used to examine this possibility. The first experiment measured the zeamatin-induced release of ultravioletabsorbing material from suspensions of C. albicans (Fig. $6 a$ ). Under these experimental conditions as little as $1 \mu \mathrm{g}$ zeamatin $\mathrm{ml}^{-1}$ produced detectable cell leakage. Although other basic proteins have been shown to cause release of cytoplasmic components from Candida (Yphantis et al., 1967), the protein concentrations required are relatively high, as can be seen from the limited release caused by $40 \mu \mathrm{g}$ lysozyme, cytochrome $c$ or BSA ml-1. A second leakage experiment was done by pre-loading $N$. crassa cells with amino $\left[1{ }^{-14} \mathrm{C}\right]$ isobutyric acid, a non-metabolizable amino acid used to measure membrane integrity (Georgopapadakou et al., 1987), and following its release from cells after treatment with zeamatin or the membrane-permeabilizing antifungal drug amphotericin B (Fig. 6b). Incubation of $N$. crassa at $30{ }^{\circ} \mathrm{C}$ with zeamatin caused an immediate loss of radioactivity that was essentially completed by $3 \mathrm{~min}$. At $0{ }^{\circ} \mathrm{C}$, release was slower but $80 \%$ of the cell-associated radioactivity was lost from the cells by $20 \mathrm{~min}$. By comparison, amphotericin B produced fairly rapid leakage at $30^{\circ} \mathrm{C}$, but no leakage occurred if cells were incubated with the drug at $0^{\circ} \mathrm{C}$. The inability of amphotericin to permeabilize membranes at $0{ }^{\circ} \mathrm{C}$ has been observed previously (Gale, 1974), and was explained in terms of immobility of the membrane lipid and/or a requirement for metabolic energy. The basic proteins lysozyme and pancreatic ribonuclease had no effect on membrane permeability of $N$. crassa.

Germinated spores of $N$. crassa were examined microscopically to determine the effect of zeamatin on hyphal morphology. In contrast to the control (Fig. 7a), incubation of $N$. crassa with zeamatin produced hyphae that stained with methylene blue and were vacuolated (Fig. 7b). Moreover, many hyphae ruptured following zeamatin addition releasing clouds of stained cytoplasm (Fig. $7 b$, arrows). Zeamatin-induced hyphal rupture occurred in less than $15 \mathrm{~s}$ at $23^{\circ} \mathrm{C}$ and with as little as $1 \mu \mathrm{g}$ zeamatin $\mathrm{ml}^{-1}$. Most, but not all, ruptures were observed at hyphal tips or immediately behind the hyphal apical dome, regions that are susceptible to turgor pressure (Wessels, 1988). Similar morphological changes were observed in hyphal forms of $C$. albicans grown as described in Fig. 5 and treated with $10 \mu \mathrm{g}$ zeamatin $\mathrm{ml}^{-1}$ (results not shown). 

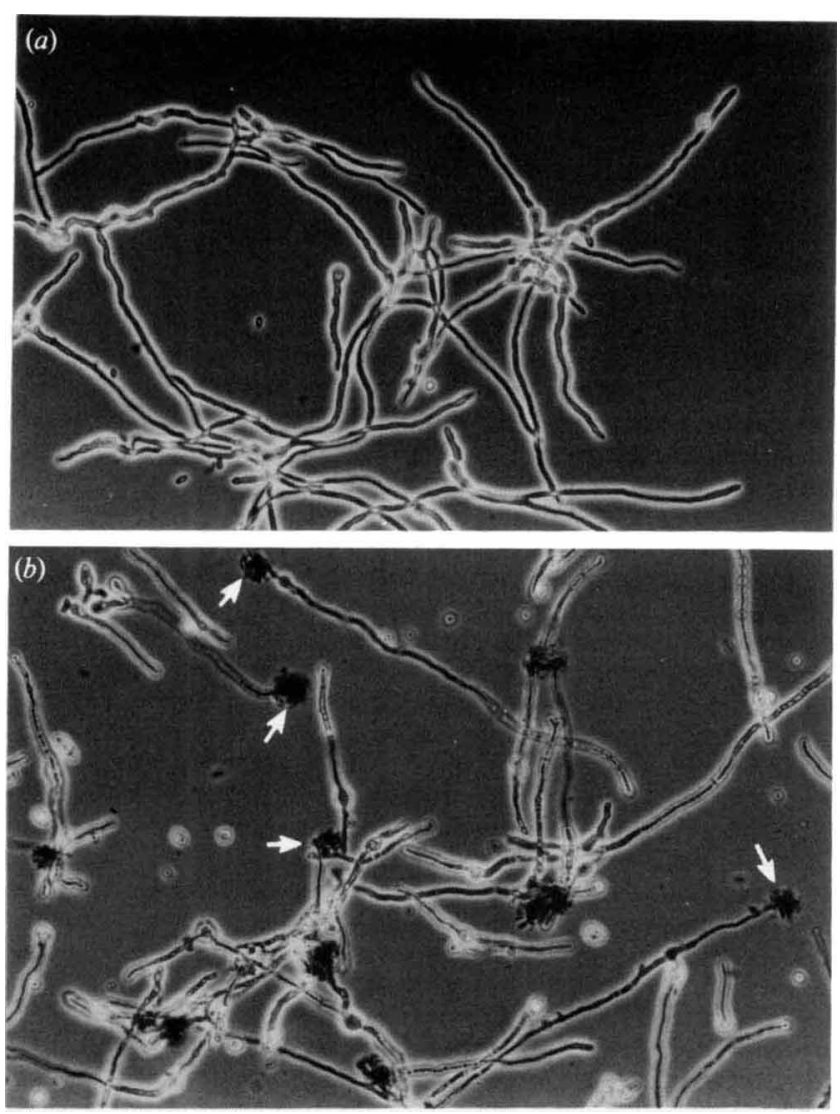

Fig. 7. Effect of zeamatin on hyphal morphology of $N$. crassa. Hyphae from germinated $N$. crassa macroconidia were incubated at $23^{\circ} \mathrm{C}$ for $10 \mathrm{~min}$ in the presence of $0.005 \%$ methylene blue and either $(a) 12 \mu \mathrm{g}$ pancreatic ribonuclease $\mathrm{ml}^{-1}$ or (b) $4 \mu \mathrm{g}$ zeamatin $\mathrm{ml}^{-1}$. Zeamatininduced hyphal rupture is seen as stained clouds of released cytoplasm (arrows). Magnification $\times 250$.

\section{Discussion}

Zeamatin's anti-Candida activity was detected originally in a partially purified chitinase preparation from maize, but not in chitinase preparations from barley and wheat (Roberts et al., 1988). The reason for this unexpected difference in antifungal activities between the chitinase preparations became apparent following further purification of the maize chitinase preparation using PhenylSepharose column chromatography (Fig. 3). Of the three enzymic activities detected in the preparation prior to Phenyl-Sepharose chromatography none eluted with the anti-Candida activity in peak 2 , indicating that zeamatin was not a chitinase or glucanase but a major protein contaminant in the maize chitinase preparation. Moreover, purified zeamatin did not hydrolyse mannan or protein, which are other common components of the fungal cell wall, making it unlikely that zeamatin's antifungal mechanism of action is enzymic hydrolysis of the cell wall. This view was strengthened by the observation that zeamatin's effect on fungi occurred very rapidly (Figs 6 and 7), even at $0{ }^{\circ} \mathrm{C}$ (Fig. 6), suggesting a non-enzymic mechanism of action.

The results shown in Figs 6 and 7 are consistent with zeamatin lysing fungi by direct insertion of the protein into fungal membranes to form transmembrane pores. A variety of proteins have been shown to lyse mammalian cells by this mechanism (Bhakdi \& Tranum-Jensen, 1987). In addition, polypeptides and proteins have been isolated from a number of sources which appear to lyse micro-organisms by a similar mechanism. These include the polypeptides melittin from bee venom (Mackler \& Kreil, 1977), cecropins from the haemolymph of insects (Steiner et al., 1981), magainins from toad skin (Zasloff, 1987), and thionins from cereals (Okada \& Yoshizumi, 1973; Bohlmann et al., 1988), as well as larger proteins like the bacteriocins colicin (Parker et al., 1989) and halocin (Torreblanca et al., 1989) and the complement attack complex (Bhakdi \& Tranum-Jensen, 1987). Many of these polypeptides and proteins have amphiphilic properties, and may act by binding to cells through a cationic region of the molecule followed by insertion of a hydrophobic domain through the lipid bilayer of the membrane. Although elucidation of zeamatin's structure must await amino acid sequencing and analysis, its amphiphilic nature is suggested by its late elution from CM-Sephadex (a cationic property) and its retarded passage through Phenyl-Sepharose (a hydrophobic property).

We have recently purified from sorghum an antifungal protein that is similar, but not identical, to zeamatin (C. P. Selitrennikoff and others, unpublished data). Moreover, we have prepared crude extracts with zeamatin-like activity (ability to act synergistically with nikkomycin to inhibit growth of C.albicans) from several other plant sources. This suggests that zeamatin is not an isolated example of a plant membrane-permeabilizing protein, but more likely a member of a family of antifungal proteins that is widespread throughout the plant kingdom, analogous to the plant chitinases. It is interesting that zeamatin, chitinases and ribosomeinactivating proteins, three proteins whose only apparent function in the plant is to inhibit fungal growth, are all stored at high concentrations in seeds. In addition, mature plants respond to microbial infection by synthesizing a group of pathogenesis-related proteins that include antifungal chitinases and glucanases (Rigden \& Coutts, 1988), as well as other uncharacterized proteins that could include proteins with zeamatin-like activity. These observations provide strong circumstantial evidence that antifungal proteins, including zeamatin, play an important role in a plant's antimicrobial defence system. Antifungal proteins have potential importance 
for increasing disease resistance in plants through genetic engineering and, in combination with nikkomycin or other antifungal drugs, for therapeutic use in medicine.

\section{References}

Bhakdi, S. \& TRANum-Jensen, J. (1987). Damage to mammalian cells by proteins that form transmembrane pores. Reviews of Physiology, Biochemistry and Pharmacology 107, 147-223.

Bohlmann, H., Clausen, S., Behnke, S., Giese, H., Hiller, C., Reimann-PhilipP, U., Schrader, G., Barkholt, V. \& APel, K. (1988). Leaf-specific thionins of barley - a novel class of cell wall proteins toxic to plant-pathogenic fungi and possibly involved in the defence mechanism of plants. EMBO Journal 7, 1559-1565.

GALE, E. F. (1974). The release of potassium ions from Candida albicans in the presence of polyene antibiotics. Journal of General Microbiology 80, 451-465.

Georgopapadakou, N. H., Dix, B. A., Smith, S. A., Freudenberger J. \& FUNKE, P. T. (1987). Effect of antifungal agents on lipid biosynthesis and membrane integrity in Candida albicans. Antimicrobial Agents and Chemotherapy 31, 46-51.

LAEMMLI, U. K. (1970). Cleavage of structural proteins during the assembly of the head of bacteriophage T4. Nature, London 227, 680-685.

MACKLER, B. F. \& KreIL, G. (1977). Honey bee venom melittin. Inflammation 2, 55-65.

Mauch, F., Mauch-Mani, B. \& Boller, T. (1988). Antifungal hydrolases in pea tissue. II. Inhibition of fungal growth by combinations of chitinase and $\beta-1,3$-glucanase. Plant Physiology 88, 936-942.

OKADA, T. \& YoshizUMI, H. (1973). The mode of action of toxic protein in wheat and barley on brewing yeast. Agricultural and Biological Chemistry 37, 2289-2294.
Parker, M. W., Pattus, F., Tucker, A. D. \& Tsernoglou, D. (1989). Structure of the membrane-pore-forming fragment of colicin A. Nature, London 337, 93-96.

Quigley, D. R., JABri, E. \& SelitrennikofF, C. P. (1987). Permeabilization of Neurospora crassa hyphae with toluene-ethanol and filipin. Current Microbiology 14, 269-274.

Rigden, J. \& CoutTs, R. (1988). Pathogenesis-related proteins in plants. Trends in Genetics 4, 87-89.

Roberts, W. K. \& Selitrennikoff, C. P. (1986a). Plant proteins that inactivate foreign ribosomes. Bioscience Reports 6, 19-29.

Roberts, W. K. \& Selitrennikoff, C. P. (1986 b). Isolation and partial characterization of two antifungal proteins from barley. Biochimica et Biophysica Acta 880, 161-170.

Roberts, W. K. \& Selitrennikoff, C. P. (1988). Plant and bacterial chitinases differ in antifungal activity. Journal of General Microbiology 134, 169-176.

Roberts, W. K., Laue, B. E. \& Selitrennikoff, C. P. (1988). Antifungal proteins from plants. Annals of the New York Academy of Sciences 544, 141-151.

Schlumbaum, A., Mauch, F., Vogeli, V. \& Boller, T. (1986). Plant chitinases are potent inhibitors of fungal growth, Nature, London 324, 365-367.

SOMOGYI, M. (1952). Notes on sugar determination. Journal of Biological Chemistry 195, 19-23.

Steiner, H., Hultmark, D., Engstrom, A., BenNich, H. \& Boman, H. G. (1981). Sequence and specificity of two antibacterial proteins involved in insect immunity. Nature, London 292, 246-248.

Torreblanca, M., Meseguer, I. \& Rodriguez-Valera, F. (1989). Halocin H6, a bacteriocin from Haloferax gibbonsii. Journal of General Microbiology 135, 2655-2661.

VoGEL, H. J. (1964). Distribution of lysine pathways among fungi: evolutionary implications. American Naturalist 98, 435-446.

WESSELS, J. G. H. (1988). A steady-state model for apical wall growth in fungi. Acta Botanica Neerlandica 37, 3-16.

Yphantis, D. A., Dainko, J. L. \& Schlenk, F. (1967). Effect of some proteins on the yeast cell membrane. Journal of Bacteriology 94, 1509-1515.

ZASLOFF, M. (1987). Magainins, a class of antimicrobial peptides from Xenopus skin: isolation, characterization of two active forms, and partial cDNA sequence of a precursor. Proceedings of the National Academy of Sciences of the United States of America 84, 5449-5453. 